\title{
Boosted Cross-Linking and Characterization of High-Performing Self-Assembling Peptides
}

\author{
Maria Gessica Ciulla ${ }^{1}$ (D), Raffaele Pugliese ${ }^{1,2}$ (D) and Fabrizio Gelain ${ }^{1,3, *(D)}$ \\ 1 Institute for Stem-Cell Biology, Regenerative Medicine and Innovative Therapies, IRCCS Casa Sollievo della \\ Sofferenza, 71013 San Giovanni Rotondo, Italy; mg.ciulla@operapadrepio.it (M.G.C.); \\ raffaele.pugliese@nemolab.it (R.P.) \\ 2 NeMo Lab, ASST Grande Ospedale Metropolitano Niguarda, 20162 Milan, Italy \\ 3 Center for Nanomedicine and Tissue Engineering (CNTE), ASST Grande Ospedale Metropolitano Niguarda, \\ 20162 Milan, Italy \\ * Correspondence: f.gelain@css-mendel.it; Tel.: +39-02-6444-7519
}

check for updates

Citation: Ciulla, M.G.; Pugliese, R.; Gelain, F. Boosted Cross-Linking and Characterization of High-Performing Self-Assembling Peptides.

Nanomaterials 2022, 12, 320 https://doi.org/10.3390/ nano12030320

Academic Editor: Miguel Gama

Received: 23 December 2021

Accepted: 16 January 2022

Published: 19 January 2022

Publisher's Note: MDPI stays neutral with regard to jurisdictional claims in published maps and institutional affiliations.

Copyright: (C) 2022 by the authors. Licensee MDPI, Basel, Switzerland. This article is an open access article distributed under the terms and conditions of the Creative Commons Attribution (CC BY) license (https:// creativecommons.org/licenses/by/ $4.0 /)$.

\begin{abstract}
Tissue engineering (TE) strategies require the design and characterization of novel biomaterials capable of mimicking the physiological microenvironments of the tissues to be regenerated. As such, implantable materials should be biomimetic, nanostructured and with mechanical properties approximating those of the target organ/tissue. Self-assembling peptides (SAPs) are biomimetic nanomaterials that can be readily synthesized and customized to match the requirements of some TE applications, but the weak interactions involved in the self-assembling phenomenon make them soft hydrogels unsuited for the regeneration of medium-to-hard tissues. In this work, we moved significant steps forward in the field of chemical cross-linked SAPs towards the goal of stiff peptidic materials suited for the regeneration of several tissues. Novel SAPs were designed and characterized to boost the 4-(N-Maleimidomethyl) cyclohexane-1-carboxylic acid 3-sulpho- $N$-hydroxysuccinimide ester (Sulfo-SMCC) mediated cross-linking reaction, where they reached $\mathrm{G}^{\prime}$ values of $\sim 500 \mathrm{kPa}$. An additional orthogonal cross-linking was also effective and allowed to top remarkable $\mathrm{G}^{\prime}$ values of $840 \mathrm{kPa}$. We demonstrated that cross-linking fastened the pre-existing self-aggregated nanostructures, and at the same time, a strong presence of $ß$-structures is necessary for an effective cross-linking of (LKLK) $)_{3}$-based SAPs. Combining strong SAP design and orthogonal cross-linking reactions, we brought SAP stiffness closer to the MPa threshold, and as such, we opened the door of the regeneration of skin, muscle and lung to biomimetic SAP technology.
\end{abstract}

Keywords: self-assembling peptides; nanofibers; Sulfo-SMCC; cross-linking; biomaterials; rheology

\section{Introduction}

The development of new nanomaterials with enhanced structural and mechanical properties is crucial to improve the outcomes of tissue engineering strategies, and for example, tackle the regeneration of either extra-soft or hard tissues. Molecular self-assembly is a powerful approach for fabricating novel supramolecular architectures [1]. This phenomenon, ubiquitous in biological systems, takes place thanks to a delicate balance between effects of solvation and different non-covalent interactions such as H-bonding, $\pi-\pi$ type or generic hydrophobic interactions, van der Waals type interactions [2]. Self-assembly and self-organization, as dominant processes in the chemistry of living biological system [3], organize small molecules into ordered structures on multiple length scales. In the recent years, researchers showed that peptides are among the best candidates for the formation of supramolecular organized scaffolds [4]. Indeed, peptide-based materials have great potential for new therapies in regenerative medicine [5] thanks to their inherent molecular recognition capabilities, biocompatibility, and negligible toxicity in biological fluids. Selfassembling peptides (SAPs) are synthetic bioactive nanomaterials used to obtain a variety of nanofibrous structures and they constitute one of the most important classes of synthetic 
self-assembling hydrogels [6]. SAP scaffolds are mimicry of the extracellular matrix (ECM), provide biochemical cues triggering biological response (e.g., cell adhesion, proliferation and differentiation), and thanks to their intrinsic versatility, they can be used for studying Alzheimer's disease [7], the regeneration of spinal cord and brain injuries [8,9], in cartilage tissue engineering [10], in cell and organoid culturing [11], drug discovery [12], bioimaging and drug delivery [13]. Nonetheless, SAPs usually give yield to soft fragile hydrogels, suited for soft tissue regeneration or as fillers [14] (Figure 1): that is why recent efforts have been focused on enhancing the mechanical properties of SAP hydrogels to match those of the tissues to be regenerated [15-19].

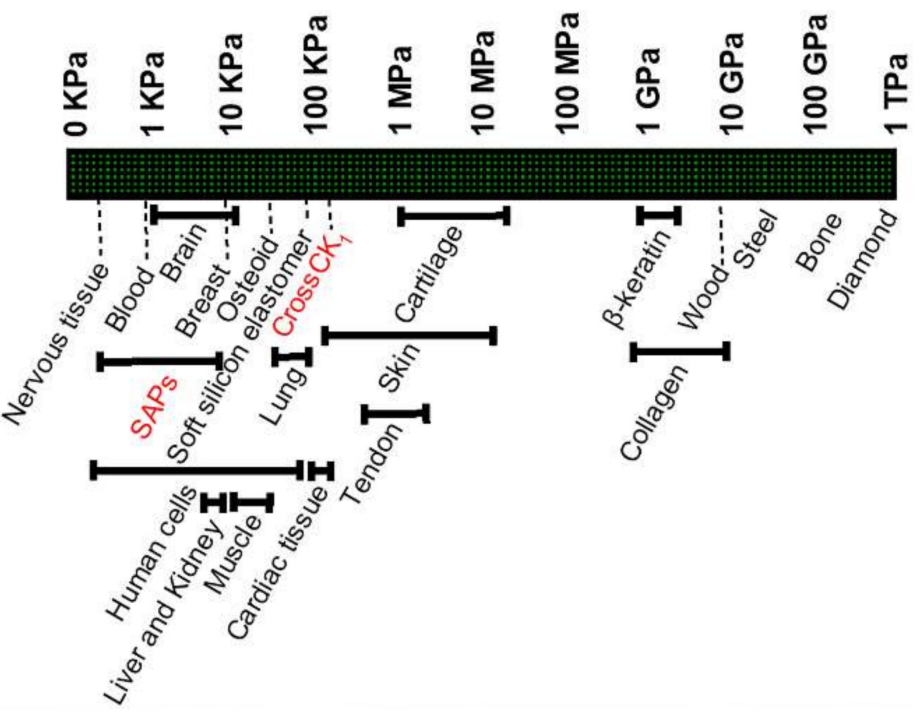

Figure 1. Elastic moduli of different tissues and materials: standard plain SAPs lay in the range of soft hydrogels. Recently published works on cross-linked SAPs showed highest $\mathrm{G}^{\prime}$ values of approximately $170 \mathrm{kPa}$, hence the typical stiffness of various tissues is still out of reach [20].

While multi-functionalization (i.e., biomimetic property) and their modifications can be considered as accomplished milestones for LDLK- or RADA-based SAPs [21]], tuning their stiffness across various orders of magnitude, in order to match that one of various living tissues (Figure 1) [20], is still an open quest. Cross-linking modifications might assist to enhance mechanical properties of a material and chemical cross-linkers are used to bind peptides and proteins for numerous applications [22]. Cross-linkers have been shown to improve scaffolds performances and thus have attracted great interest [23]. Various cross-linking methods are available, both physical and chemical and they can be classified according to their chemical specificity; to the length of the cross-bridge formed; to the homobifunctionality or heterobifunctionality of the cross-linker; to the type of reaction (e.g., chemical or photo-chemical); to the presence of a cleaved bond in the reaction; and to the amenability for further radiolabeling [24]. Heterobifunctional cross-linkers have two different groups allowing for sequential conjugations: among them, some cross-linkers contain an NHS ester with a second functional group capable of binding to a sulfhydryl. A common sulfhydryl-reactive group is the maleimide moiety, that reacts with cysteine residues in slightly acidic-to-neutral conditions [25]. Sulfo-SMCC is an NHS-ester end of a heterobifunctional cross-linker reactive against primary amines of lysine, making a maleimide-activated peptide. At the same time, sulfhydryl groups react with the maleimide groups, thus yielding to a "molecular bridge" (Figure 2a) [26].

In our previous study [27], we demonstrated the increased mechanical properties of a promising SAP, $\mathrm{CK}_{1}$ (the top one in Figure $2 \mathrm{~b}$ ), after Sulfo-SMCC cross-linking reaction, wherein the peptide was covalently cross-linked to make a stronger gel [6]. Despite the significant advance, a good percentage of unreacted primary amines and sulfhydryl groups was left at the end of the reaction, demonstrating the chance for further improvements of 
the proposed approach. Here, three new SAPs belonging to the CK family (Figure $2 b$ ), $\mathrm{CK}_{2}$, $\mathrm{CK}_{3}$ and $\mathrm{CK}_{4}$, were designed, synthesized and characterized to explore their mechanical properties, evaluate their self-assembling propensity, their reactivity to the cross-linking reaction and, as such, their feasibility as high-performing peptidic scaffolds. Furthermore, we reported the combined double cross-linking of SAPs via Sulfo-SMCC and Genipin (GP) (a natural cross-linker), where peptides were firstly covalently linked with Sulfo-SMCC, and consequently treated with GP [28]. The final aim was to saturate all available binding sites in peptide sequences by boosting this cross-linking approach to the maximum limit, and as such, to assess its potential in terms of enhanced scaffold stiffness. The designed $\operatorname{crossCK}_{n}$ and $\operatorname{cross}_{\mathrm{CK}}$-GP were characterized and investigated by measurements and experimental assays, testifying the increased mechanical toughness of the biomaterials after cross-linking reaction, but also the limit to the proposed strategy in terms of SAP functionalization.
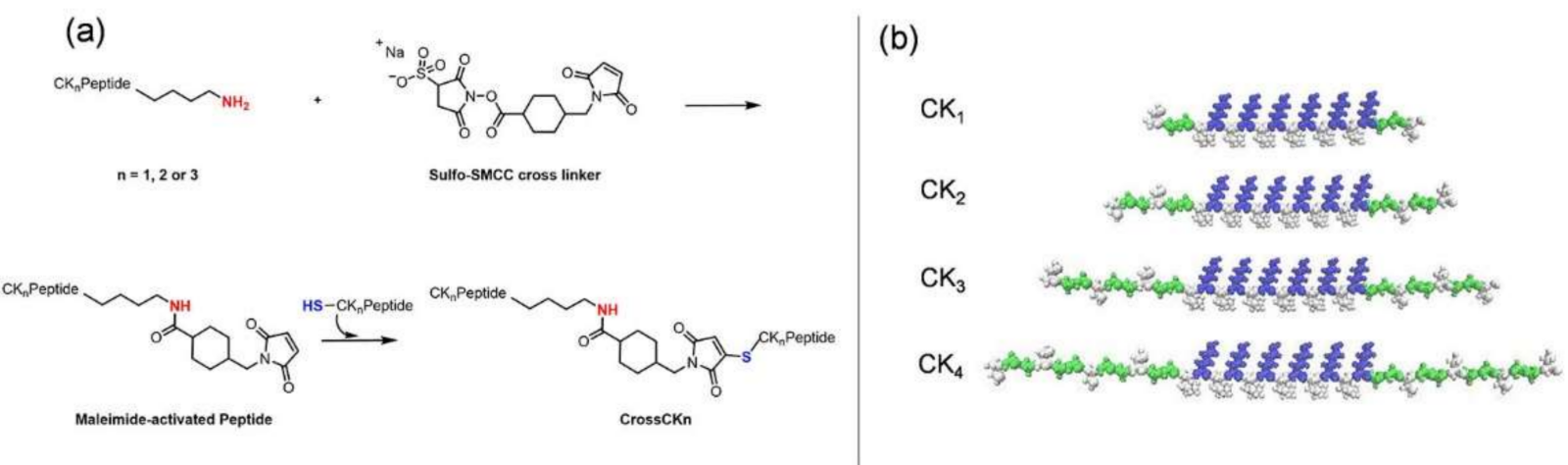

Figure 2. (a) Scheme of reaction mechanism of Sulfo-SMCC cross-linking as suggested by seller Termofisher (link at: https: / /www.thermofisher.com/order/catalog/product/22322 accessed on 14 January 2022) [26]. The preparation of crossCKs peptides undergoes a two-steps conjiugation with a molar excess of the cross-linker. (b) VDW representation of $\mathrm{CK}_{1}, \mathrm{CK}_{2}, \mathrm{CK}_{3}$ and $\mathrm{CK}_{4}$ molecules. Coloring method follows residue type.

In this scenario, crossCK $\mathrm{n}_{\mathrm{n}}$ materials may represent new versatile synthons in the SAPs family, which can be additionally double-cross-linked, orthogonally functionalized, and as such, can be considered steppingstones for novel applications.

\section{Materials and Methods}

\subsection{Materials}

All chemicals were purchased from Merck (Merck Millipore, Darmstadt, Germany), Sigma Aldrich (Sigma Aldrich Chemie GmbH, München, Germany) and VWR (Radnor, PA, USA) in highest quality commercially available. The solvents are capable of RP (Reverse Phase). Fmoc-protected amino acids were obtained from CEM (Matthews, NC, USA) and used as received without further purification. Sulfo-SMCC was purchased from Thermo Fisher (Fischer Scientific GmbH, Schwerte, Germany). The structure of intermediates and the final products were evaluated through exact MS and IR. LC-MS spectra were recorded via single quadrupole mass detection (Waters LC-MS Alliance 3100, Waters Corp., Milford, CT, USA) using a nebulizing nitrogen gas at $400 \mathrm{~L} / \mathrm{min}$ and a temperature of $250{ }^{\circ} \mathrm{C}$, cone flow $40 \mathrm{~mL} / \mathrm{min}$, capillary 3.5 Kvolts and cone voltage $60 \mathrm{~V}$; or with a Waters ACQUITY UPLC system (Waters Corp., Milford, CT, USA) coupled with a Waters Xevo G2-XS QTof Mass Spectrometer in a positive mode using a temperature of $150{ }^{\circ} \mathrm{C}$, cone flow $20 \mathrm{~mL} / \mathrm{min}$, capillary $3 \mathrm{kVolts}$ and cone voltage $20 \mathrm{~V}$.

\subsection{General Procedure for Peptides Synthesis}

Synthesis was carried out via microwave solid-phase Fmoc-based chemistry using a CEM Liberty Blue system (CEM Corp., Matthews, NC, Canada) on a $0.25 \mathrm{mmol}$ scale 
in excess of a $0.2 \mathrm{M}$ amino acid solution (in DMF) with $1 \mathrm{M}$ DIC (in DMF) as an activator and $1 \mathrm{M}$ Oxyma (in DMF) as an activator base. A $0.56 \mathrm{mmol} / \mathrm{g}$ Rink Amide resin was used for the synthesis of $\mathrm{CK}_{1}$ and $\mathrm{CK}_{2}$, while a $0.19 \mathrm{mmol} / \mathrm{g}$ Rink Amide resin was used for $\mathrm{CK}_{3}$ and $\mathrm{CK}_{4}$. Fmoc-protected amino acids were dissolved at $0.2 \mathrm{M}$ in DMF and the deprotection solution used for the removal of Fmoc groups was a 10\% $v / v$ of piperazine in 9:1 NMP/EtOH solution. The N-terminal was acetylated using a $20 \% v / v$ solution of $\mathrm{Ac}_{2} \mathrm{O}$ in DMF. The peptide resin was washed three times with $\mathrm{CH}_{2} \mathrm{Cl}_{2}$ immediately after synthesis. Cleavage was then performed in $10 \mathrm{~mL}$ of a freshly prepared TFA: $\mathrm{H}_{2} \mathrm{O}: \mathrm{DODt}$ TIS (92.5:2.5:2.5:2.5) solution for 30 min utilizing a CEM RAZOR System with a temperature set at $38{ }^{\circ} \mathrm{C}$. The resin was then filtered and the TFA solution added to ice cold diethyl ether for precipitation and then lyophilized (Labconco, Kansas City, MO, USA). Purification of the crude material was carried out using a Waters binary HPLC $(>96 \%)$ on a Restek ${ }^{\mathrm{TM}}($ Restek Corp., Bellefonte, PA, USA) Prep C18 column. The mobile phase consisted of a gradient of acetonitrile with $0.1 \%$ TFA and $\mathrm{H}_{2} \mathrm{O}$ with $0.1 \%$ TFA over $30 \mathrm{~min}$. After semi-preparative HPLC purification, the isolated product was used to the final concentrations (see analytical section in Supplementary Materials).

\subsection{Cross-Linking Reaction}

A solution (1:1 $\mathrm{H}_{2} \mathrm{O}$ :DPBS) of Sulfo-SMCC was slowly added to a previously dissolved $20 \mathrm{mM}$ of all $\mathrm{CK}_{\mathrm{s}}$ (2 equiv., 4 equiv., 6 equiv. and 8 equiv. for, respectively, $\mathrm{CK}_{1}, \mathrm{CK}_{2}, \mathrm{CK}_{3}$ or $\mathrm{CK}_{4}$. After addition, the reaction was stirred overnight at room temperature. Then the unreacted Sulfo-SMCC was removed with a vacuum pipette. Finally, the cross-linked material was washed with DPBS.

For double cross-linking, a solution of $170 \mathrm{mM}$ of GP dissolved in 95:5 $\mathrm{H}_{2} \mathrm{O}$ :EtOH was added to crossCKs, and the reaction solution was then incubated at $37^{\circ} \mathrm{C}$. After $24 \mathrm{~h}$, the crossCKn-GP was washed five times with DPBS to remove the unreacted GP.

\subsection{Characterization of SAPS and Cross-SAPS}

\subsubsection{Rheological Characterization}

Rheological characterization of the prepared materials at different concentrations (see Results for details) was performed by the rotational AR-2000 ex rheometer (TA Instruments, Waters Corp., Milford, CT, USA). A cone-plate configuration with an acrylic diameter of $20 \mathrm{~mm}$ and a truncation of $34 \mu \mathrm{m}$ and angle 1\% was used. Exclusively for the double cross-linking with GP a plate-plate configuration with a diameter of $20 \mathrm{~mm}$ was used. The temperature for rheological tests was set to $25^{\circ} \mathrm{C}$. A time sweep experiment was performed at $1 \mathrm{~Hz}$ constant angular frequency, followed by a frequency sweep test $(1-1000 \mathrm{~Hz})$ at the constant strain of $1 \%$ in the linear viscoelastic range experiments and as a function angular frequency. Stress/strain amplitude was performed from $0.01 \%$ to $1000 \%$. G' (storage modulus) and $G^{\prime \prime}$ (loss modulus) representing, respectively, the solid-like and the liquidlike behavior of the materials recorded. All measurements were performed in triplicate and curves were processed with OriginPro 2019 (OriginLab Corporation, Northampton, MA, USA). All results regarding the loss modulus $\mathrm{G}^{\prime \prime}$ experiments were reported in the Supplementary Materials.

\subsubsection{Fourier-Transform Infrared Spectroscopy in Attenuated Total Reflection Mode (ATR-FTIR) Analysis}

Attenuated total reflection spectra were collected using a Perkin-Elmer Spectrum Two IR spectrometer (PerkinElmer Ltd., Beaconsfield, United Kingdom) equipped with a Perkin-Elmer single-reflection diamond ATR. The spectra of the samples were measured in the range of 400 to $4000 \mathrm{~cm}^{-1}$ at room temperature. Particular attention was paid in the infrared spectra in the Amide A, Amide I, Amide II band regions. The spectra were analyzed using OriginPro 2019 (OriginLab Corporation, Northampton, MA, USA). Firstly, baseline correction was performed, and hidden peaks were detected using a second derivative method followed by smoothing with the 7-9 point Savitsky-Golay function with 
a polynomial order of 2. Peak fitting/deconvolution was then performed using the Voigt function from OriginPro which is the convolution of a Gaussian function and a Lorentzian function [29].

\subsubsection{Thioflavin-T (ThT) Binding Assay}

The benzothiol dye ThT was used to detect the $\beta$-sheets in CKs and cross-CKs: ThT links $\beta$-sheets [30] in a fibril-ligand interaction between dye and rows of repetitive amino acid patterns running perpendicular to the strands that represent a ubiquitous structural feature of fibril-like surfaces. A solution of $20 \mathrm{mM} \mathrm{CK}$ in milli-Q water (pH 7.4) was mixed with a ThT working solution (ThT/ $\mathrm{CK}_{\mathrm{n}}$ 0.5:1) and was stirred for $2 \mathrm{~min}$ [31]. ThT fluorescence measurements were recorded using an Infinite M200 Pro plate reader (Tecan, Mennedorf, Switzerland) with excitation at $440 \mathrm{~nm}$ and emission $482 \mathrm{~nm}$. All measurements were carried out in $1 \mathrm{~cm}$ path length micro-fluorescence cells.

2.4.4. Quantification of Amino Groups on the Uncross-Linked via 2,4,6-Trinitrobenzene Sulfonic Acid (TNBSA) Assay

This method is used to indirectly determine the number of the remaining unmodified lysine residues after the cross-reaction [32]. TNBSA in $0.1 \mathrm{M}$ aqueous buffer at pH 8.5 was added to a $20 \mathrm{mM}$ peptide solution in $\mathrm{H}_{2} \mathrm{O}$ and the reaction was stirred for $2 \mathrm{~h}$ at $37^{\circ} \mathrm{C}$. The reaction mixture was quenched with a solution of $1 \mathrm{~N} \mathrm{HCl}$. Reaction with primary amines was observed by producing a chromogenic yellow colored derivative and the absorbance was recorded in the ultraviolet light at $335 \mathrm{~nm}$ using an Infinite M200 Pro plate reader (Tecan). Absorbance curve resulting from TNBSA assay was monitored at $0,2,4,6,8$ and $24 \mathrm{~h}$. All measurements were carried out in triplicate in $1 \mathrm{~cm}$ path length micro-fluorescence cells and processed with OriginPro using Boltzmann fitting.

\subsubsection{Quantification of Free Thiols Using Ellman's Reagent}

In a $1 \mathrm{~cm}$ sample cuvette, $100 \mu \mathrm{L}$ of freshly prepared Ellman's solution [33] were added to a $20 \mathrm{mM}$ peptide aqueous solution. After mixing for $15 \mathrm{~min}$, free thiols percentage was recorded by reading the absorbance in an Infinite M200 Pro plate reader (Tecan) at $412 \mathrm{~nm}$. The calculations from molar absorbance of TNB anion giving $\mathrm{E}_{412}$ was $\mathrm{TNB}^{-2}=1.36 \times 10^{4} \mathrm{~cm}^{-1} \mathrm{M}^{-1}$. Absorbance curve resulting from Ellman's assay was monitored at $0,2,4,6,8$ and $24 \mathrm{~h}$. All measurements were carried out in $1 \mathrm{~cm}$ path length micro-fluorescence cells and processed with OriginPro using Boltzmann fitting.

\subsubsection{Atomic Force Microscopy (AFM) Analysis}

Images captured were obtained in tapping mode using a Multimode Nanoscope $\mathrm{V}$ (Digital Instruments, Veeco, Plainview, NY, USA), with a single cantilever beam probe (Veeco RFESP MPP-21100-10, cantilever f0, 76-90 kHz). When necessary, data sets were subjected to a first-order flattening. Measured fiber dimensions were corrected because of the convolution effect arising from the finite size of the AFM tip. The observed nanofiber heights being far lower than the tip radius and the observed widths could be corrected with the formula [34]:

$$
\Delta x=\sqrt{2[h(2 r t-h)]}
$$

where $\Delta x$ is the width broadening effect, $h$ is the nanofiber height, and $r t$ is the tip radius. AFM images were traced using FiberApp software [35].

\section{Results and Discussion}

\subsection{Design of High-Performing Cross-Linked SAPS}

In the search of bioinspired synthons for biomaterials design, the sol-to-gel transition of SAPs was combined with a strong cross-linker such as Sulfo-SMCC. We designed novel $\mathrm{CK}_{\mathrm{n}}$ taking inspiration from our previously reported results, where the peptide sequence called $\mathrm{CK}$, now dubbed $\mathrm{CK}_{1}$, showed increased stiffness and tailorability once treated with 
Sulfo-SMCC, without undermining its self-assembling propensity. We focused our efforts on modulating the length of the peptide chains and on the optimization of the concentration of Sulfo-SMCC in reference to the number of sulfhydryl groups introduced. The chosen self-assembly backbone is LKLK12 (Ac-LKLKLKLKLKLK-CONH ${ }_{2}$ ) [36], that self-assembles and triggers a sol-to-gel transition upon exposure to a basic pH-shift. LKLK12 backbone, positively charged due to Lys alternated pattern, was used in our previous studies32 on complementary co-assembling peptide (CAP) hydrogels based on mutual-attraction and self-repulsion of positive and negative modules. Functionalization of LKLK12 backbone was designed by keeping in mind the need for a glycine-spacer [37], usually present in standard SAPs, to preserve both the $\beta$-structuring of the backbone and the exposure of the added functional/active motifs. Although a good stiffness value $\left(\mathrm{G}^{\prime}=170 \mathrm{kPa}\right)$ with $\mathrm{CK}_{1}$ was achieved in our previous work, this was still far from covering the stiffnesses required in tissue engineering applications other than those of soft tissues [38]. Furthermore, the detected presence of unreacted amine groups at the end the cross-linking reaction pointed at additional room for improvement of the proposed strategy, e.g., increasing the number of sulfhydryl active sites on the SAP termini while preserving the same self-assembling backbone. Thus, three novel peptides, $\mathrm{CK}_{2}, \mathrm{CK}_{3}$ and $\mathrm{CK}_{4}$, belonging to the $\mathrm{CK}$ family were synthesized and evaluated to improve the performances of $\mathrm{CK}_{1}$.

All $\mathrm{CK}_{\mathrm{n}}$ are symmetrical peptides against to the central backbone: they incorporate increasing numbers of repeated units of (Cys-Gly-Gly) $n$ and (Gly-Gly-Cys) $n$ at both ends, with $n=1,2,3,4$, respectively for $\mathrm{CK}_{1}, \mathrm{CK}_{2}, \mathrm{CK}_{3}$ and $\mathrm{CK}_{4}$ (see Figure 1 above) (see Supplementary Materials).

\subsection{Rheology}

Rheological properties are indicators of the strength of a fibrillar network, and its stiffness tunability well-correlates with the range of potential applications in biotechnology. To investigate the mechanical properties of SAP scaffolds, we evaluated the storage $\left(\mathrm{G}^{\prime}\right)$ and loss $\left(\mathrm{G}^{\prime \prime}\right)$ moduli as function of angular frequency [39] (Figure 3).

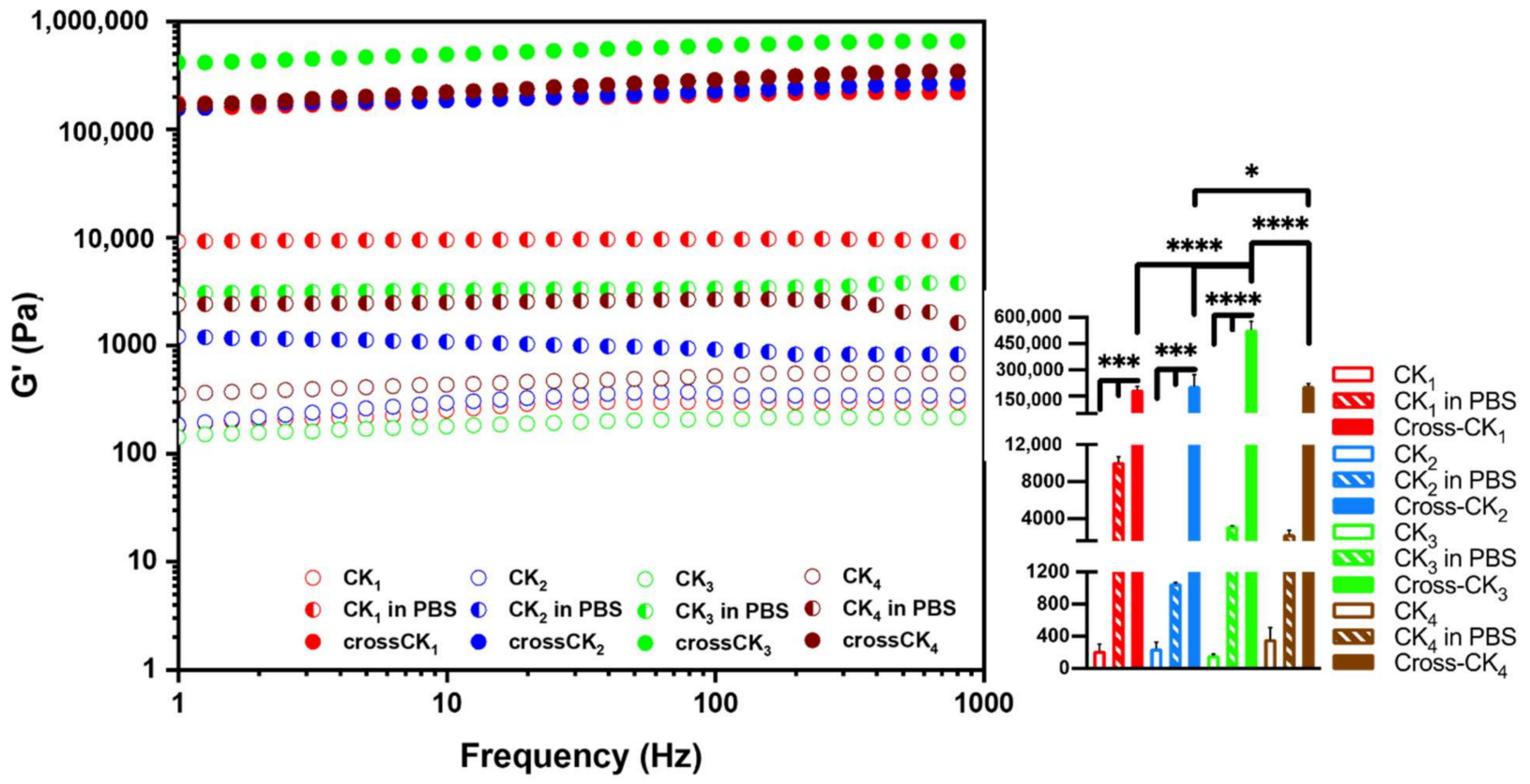

Figure 3. Rheological tests. The mean values of elastic moduli, $\mathrm{G}^{\prime}$, calculated after Sulfo-SMCC cross-link reaction $(15 \mathrm{~h})$ via a frequency-sweep test. All experiments were performed in triplicate. Cross $\mathrm{CK}_{3}$ tops an average $\mathrm{G}^{\prime}$ value around $532 \mathrm{kPa}$. Statistical analysis was performed by Ordinary One-way ANOVA. ${ }^{*} p<0.01,{ }^{* * *} p=0.001$ and ${ }^{* * * *} p<0.0001$ indicate the significance regarding stiffness of materials analyzed. 
The initial peptide concentration was $20 \mathrm{mM}$, that is the maximum concentration warranting appropriate solubility for this kind of SAPs. After self-assembling (i.e., addition of PBS), all $C_{n}$ showed $G^{\prime}>G^{\prime \prime}$, confirming their solid-like behavior (Figure 1 and Figure S1, Tables S1 and S2). In general, the cross-linking reaction was expected to increase the stiffness of all tested SAPs. Furthermore, all the crossCKs storage moduli were $>100 \mathrm{kPa}$, ranking their stiffness between those of platelets and cartilage.

Best results were achieved with crossCK 3 with a $\mathrm{G}^{\prime}$ value of $(532 \pm 44) \mathrm{kPa}$. Our data confirmed that the number of $\mathrm{Cys}$ is the major factor responsible for the increase of storage moduli: indeed, $\mathrm{G}^{\prime}$ values are higher in the ascending order $\left(\mathrm{CK}_{3}>\mathrm{CK}_{2}>\mathrm{CK}_{1}\right)$. Nonetheless, we faced a chain length limit to this approach, being both $\mathrm{G}_{\mathrm{CK} 4}^{\prime}$ and $\mathrm{G}_{\text {crossCK4 values }}$ lower than, respectively $\mathrm{G}_{\mathrm{CK} 3}^{\prime}$ and $\mathrm{G}_{\text {crossCK3 }}^{\prime}$ Similarly to RADA16-I, RADA16-II, EAK16, and KLDL12 [40], which are 12-30 residues in length, the formation of supramolecular cross- $\beta$ structures comes from a subtle balance between hydrophobic and electrostatic interactions [41], responsible for their self-assembly propensity [42]. We hypothesized that overlong functional motifs may have influenced the molecular structuration, and primary amines exposure, of the self-assembling backbones of $\mathrm{CK}_{3}$ and $\mathrm{CK}_{4}$.

Hence, different preparations of SAPs were tested to verify if, deviating from the standard SAP handling protocol (i.e., overnight incubation at $+4{ }^{\circ} \mathrm{C}$ prior usage), was detrimental or beneficial to the overall performance of crossCK$_{n}$. We assessed the outcomes of cross-linking reactions as a result of variations of the incubation times of CK dissolved in water (allowing for the spontaneous formation of loosely interacting nanofibers) [43] and also in relation to different CK concentrations (Supplementary data, Table S1).

In summary, SAP concentration decrements and shortening of the incubation time prior to self-assembling and cross-linking were detrimental to the mechanical properties of crossCK $\mathrm{K}_{\mathrm{n}}$ (see supplementary results) and the standard SAP preparation protocol was confirmed to be the best one. Lastly, even though crossCK $\mathrm{K}_{4}$ did not place itself at a higher position than cross $\mathrm{CK}_{3}$, all crossCK $\mathrm{K}_{\mathrm{n}}$ with $20 \mathrm{mM}$ initial concentration have achieved values of $\mathrm{G}^{\prime}$ between $(170 \pm 16) \mathrm{kPa}$ and $(532 \pm 44) \mathrm{kPa}$.

\subsection{ATR-FTIR Experiments}

In ATR-FTIR experiments, infrared radiation absorption spectra were studied in the amide I, II, and A bands. All ATR-FTIR spectra showed the presence of the typical absorption bands of peptides at $3270 \mathrm{~cm}^{-1}, 2930 \mathrm{~cm}^{-1}, 1623 \mathrm{~cm}^{-1}$, and $1532 \mathrm{~cm}^{-1}$, ascribable respectively to the stretching vibrational bands of $-\mathrm{NH}_{2}, \mathrm{C}-\mathrm{H}$ aliphatic, $\mathrm{C}=\mathrm{O}$ acetyl and to the bending vibrational band of $\mathrm{N}-\mathrm{H}$ (Figure $4 \mathrm{a}$ ). Moreover, data confirmed the presence of $\beta$-sheet-rich fibers formed after self-assembly [44].

In the Amide I band (Figure 4a), the acetyl group stretching vibration of the peptide bond was observed, demonstrating the sensitivity to the secondary structure and the $\beta$-sheet intermolecular interactions of the peptides at 1623 [45].

In the Amide II region, the absorption bands display the bending vibrational bands of the $\mathrm{N}-\mathrm{H}$ group (as a consequence of the $\mathrm{NH}_{2}$ deformation in primary amides) and the $\mathrm{N}-\mathrm{H}$ bending and C-N stretching vibrations in secondary amides [46]. In the Amide II region, the major contribution came from the strong sharp absorption band at $1532 \mathrm{~cm}^{-1}$ ascribable to the $\mathrm{C}=\mathrm{O}$ stretching. In the cross-linked compounds it was also possible to reveal the shift of the stretching vibrational bands from $\sim 1620 \mathrm{~cm}^{-1}$ to $\sim 1625 \mathrm{~cm}^{-1}$ because of cross-linking between $\mathrm{CK}_{\mathrm{n}}$ and Sulfo-SMCC. Furthermore, the Amide A region (Figure $4 \mathrm{~b}$ ) showed peak frequencies typical of a weakly hydrogen bonded NH moiety and a free NH stretch: the peak near $\sim 3300 \mathrm{~cm}^{-1}$ indicates the presence of medium strength H-bonds, typical of $\beta$-sheet structures.

Mathematical procedures such as Fourier second derivatives and deconvolution were used to resolve the overlapping bands (see Figure S4 in Supplementary Materials). All peptide spectra displayed the presence of intermolecular $\beta$-sheet structures with strong $\mathrm{H}$ bonds $\left(1623 \mathrm{~cm}^{-1}\right)$ and with high frequency components $\left(1695 \mathrm{~cm}^{-1}\right)$. Given the increments in the components ascribable to $\beta$-structures found in crossCK $\mathrm{CK}_{1-3}$ if compared to $\mathrm{CK}_{1-3}$, it is 
evident that cross-linking with Sulfo-SMCC favors tighter $\beta$-sheets packing of $\mathrm{CK}_{1-3}$, likely contributing to the overall increased mechanical properties we previously demonstrated.

(a)

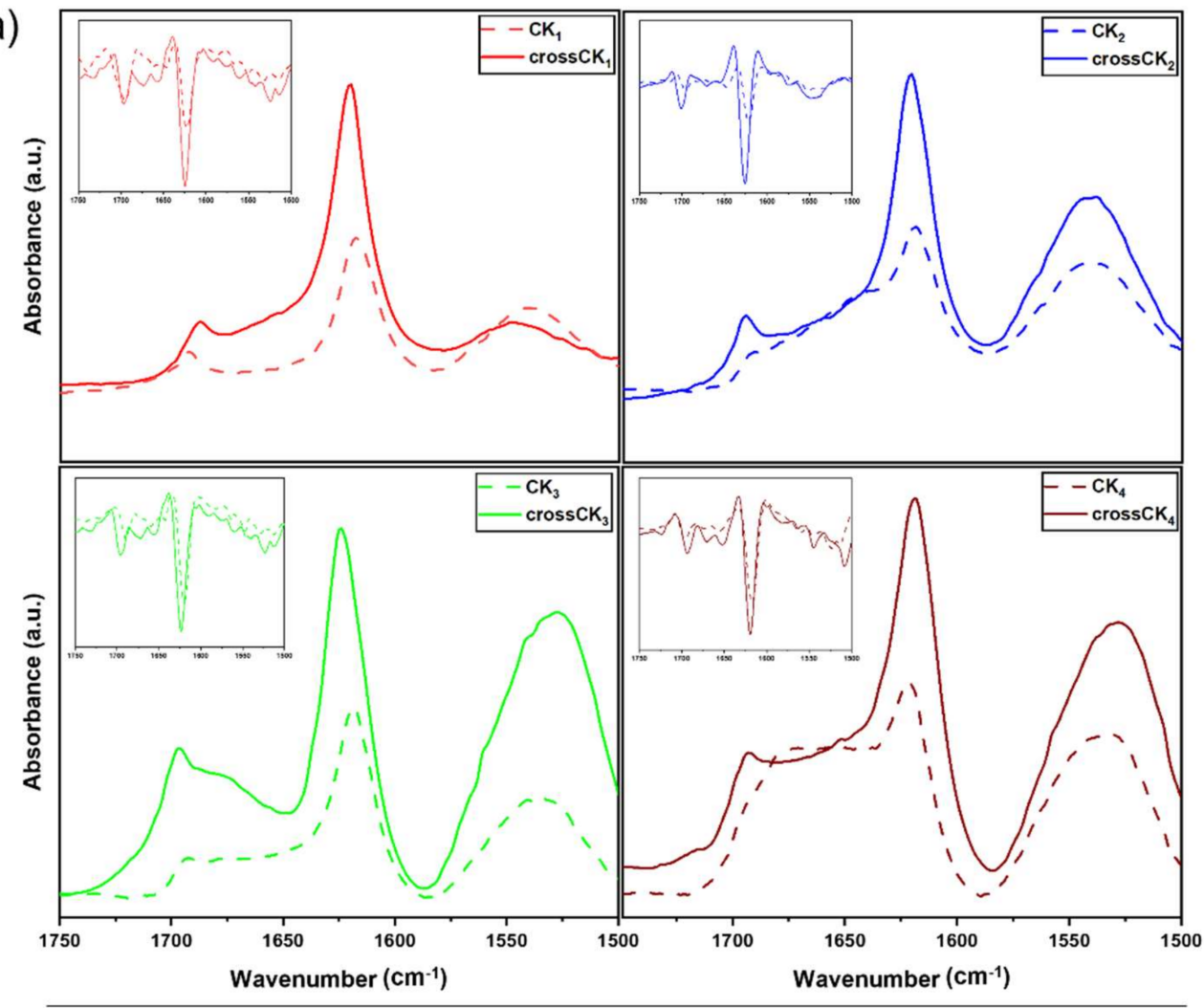

(b)

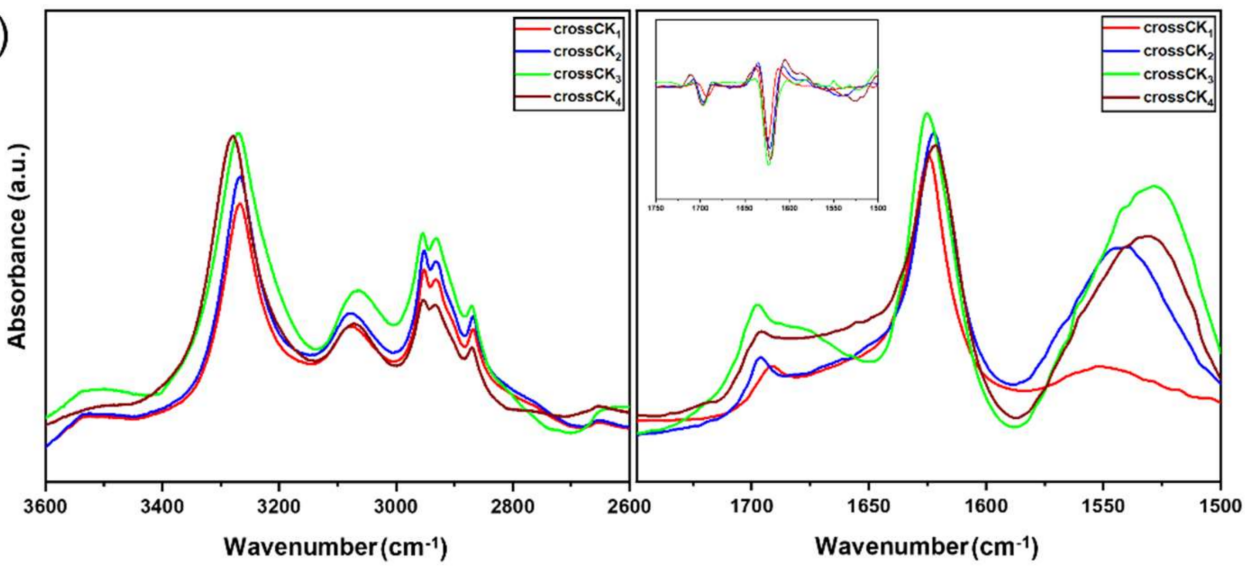

Figure 4. Experimental ATR-FTIR absorption spectra of $\mathrm{CK}_{n}$ and crossCK $\mathrm{K}_{n}$ (a) $\mathrm{CK}_{1-4}$ and crossCK $1-4$ spectra in the Amide I-II band with their respective second derivatives (inserts). Both $\mathrm{CK}_{1-4}$ and crossCK $\mathrm{CK}_{1-4}$ peptides showed typical features of $\beta$-sheet structures at $\sim 1620 \mathrm{~cm}^{-1}$ and at $\sim 1695 \mathrm{~cm}^{-1}$. (b) Comparison among crossCK $\mathrm{C}_{1-4}$ in the Amide A (on the left) and Amide I-II regions (on the right). All experiments displayed $\beta$-sheet structures at $\sim 3300 \mathrm{~cm}^{-1}$ and the greatest absorption for $\mathrm{crossCK}_{3}$ at $\sim 1695 \mathrm{~cm}^{-1}$ : all curves showed an increase of $\beta$-sheet structuration in the Amide I region once cross-linking occurred.

On the other hand, amide I peak deconvolution for $\mathrm{CK}_{4}$ showed a more heterogeneous composition of secondary structures comprising $\alpha$-helix, $\beta$-sheets, and coils. This observation points out that the increase of the peak intensity between $1647 \mathrm{~cm}^{-1}$ and $1700 \mathrm{~cm}^{-1}$ is probably due to chain-length dependent aggregated superstructures rather than to $\beta$-sheets increments, thus presumably decreasing the order and packing of active sites, found to be crucial for efficient cross-linking [46]. 


\subsection{Degree of Cross-Linking by ThT, TNBSA and Elmann's Assays}

ThT assay showed fluorescence intensity increments due to $\beta$-sheets formation reaching highest values once cross-linking was formed (Figure 5a).

(a)
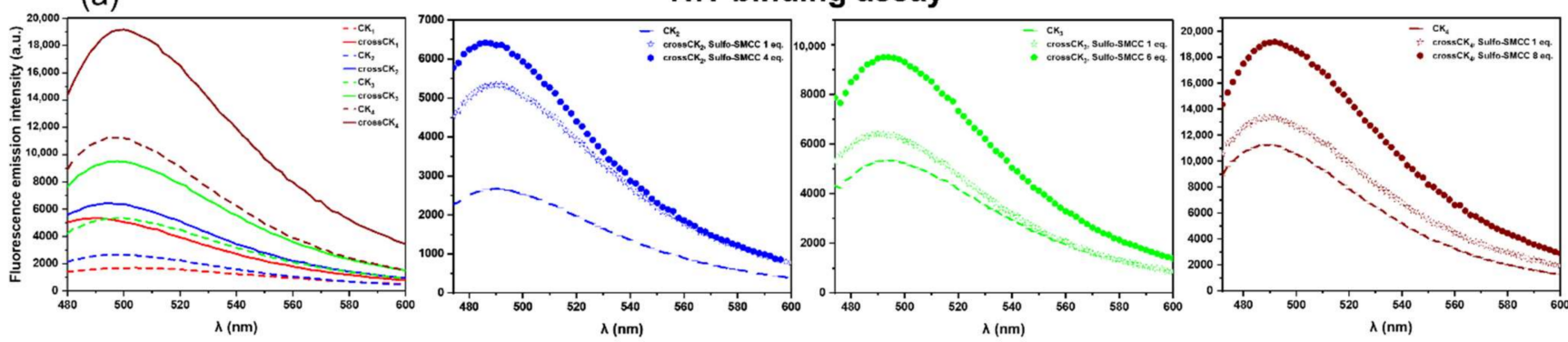

(b)

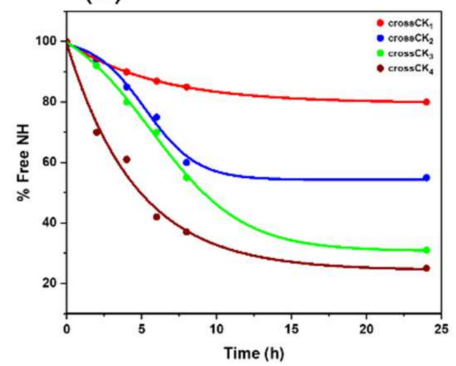

TNBSA assay

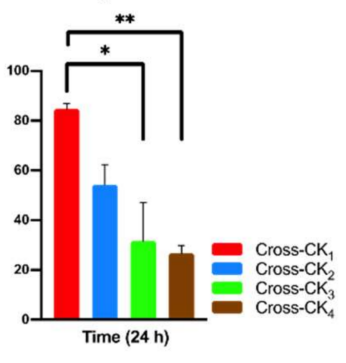

(c)

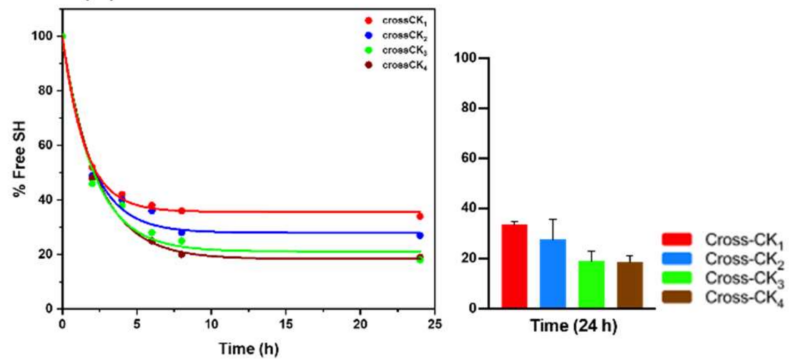

Figure 5. ThT, TNBSA and Ellman's assays. (a) ThT fluorescence emission spectra of $\mathrm{CK}_{1-4}$ before and after Sulfo-SMCC cross-linking (Sulfo-SMCC $=2,4,6,8$ equivalents for respectively, $\mathrm{CK}_{1}, \mathrm{CK}_{2}$, $\mathrm{CK}_{3}$ and $\mathrm{CK}_{4}$ ). To the right, ThT spectra of $\mathrm{CK}_{2-4}$ at various concentrations of Sulfo-SMCC: ThT fluorescence levels increased when number of equivalents of Sulfo-SMCC used for the cross-linking reaction matched those of Cys available for binding. (b) Absorbance curves from TNBSA assay: all experiments showed a decrease in the free amine percentage during the time course of the reaction: increasing the number of Cys significantly contributed to the decrease of free $-\mathrm{NH}_{2}$ groups at the end of the reaction. (c) Absorbance curve from Ellman's assay. All crossCK peptides showed a decrease in free $\mathrm{SH}$-groups during the time course of the reaction until the plateau was reached. In both $(\mathbf{b}, \mathbf{c})$, bars represent the standard deviation of the mean calculated at $24 \mathrm{~h}$ where ${ }^{*} p=0.0123,{ }^{*} p=0.0074$. Statistical analysis was performed by Ordinary One-way ANOVA.

As expected, ThT was shown to bind with favorable affinity to all CKs structures, confirming the presence of $\beta$-sheet packed secondary structures in both hydrogels and cross-linked scaffolds. Historically, ThT was used to detect cross- $\beta$ rich structures only due to the characteristic sigmoidal fluorescence increase occurring from the monomer to the end fibril states. A further optimization was made by adjusting the concentration of Sulfo-SMCC in the cross-linking reaction in accordance with the number of Cys-Gly-Gly motif present in $\mathrm{CK}_{2}, \mathrm{CK}_{3}$ and $\mathrm{CK}_{4}$.

Results demonstrated that cross-linking increases the $\beta$-structuration of all $\mathrm{CK}_{\mathrm{n}}$, but also the importance of using the proper equivalents of Sulfo-SMCC matching the number of cysteine residues found in each peptide; indeed, the ThT signal increased along with the concentration of Sulfo-SMCC (Figure 5a).

Furthermore, cross $\mathrm{CK}_{\mathrm{n}}$ peptides were analyzed by TNBSA assay to indirectly quantify the unmodified free amino groups present in the cross-linked products. As shown in Figure $5 b$, all cross $\mathrm{CK}_{n}$ showed a decreasing percentage of free- $\mathrm{NH}_{2}$ immediately after the beginning of the cross-linking reaction, plateauing after $24 \mathrm{~h}$.

Similarly, Ellman's assay was used to determine the amount of free cysteine/sulfhydryl groups present in the reaction mix [47]. Ellman's assay values decreased and plateaued 
with comparable timings to TNBSA, confirming the kinetic of cross-linking reaction and depletion of free $\mathrm{SH}$-groups (Figure $5 \mathrm{c}$ ). In $\mathrm{CK}_{1}, \mathrm{CK}_{2}$ and $\mathrm{CK}_{3}$ the increased numbers of Cys residues allowed for a higher percentage of $-\mathrm{NH}_{2}$ to be involved in the cross-linking reaction and was not detrimental to the percentage of remaining free $\mathrm{SH}$-groups. In the case of $\mathrm{CK}_{4}$, no significant improvements were detected if compared to $\mathrm{CK}_{3}$, both in terms of free $-\mathrm{NH}_{2}$ and $\mathrm{SH}$ - groups, likely for its more heterogeneous structuration detected in ATR-FTIR data, hampering appropriate exposure and stable "proximity" of active sites to statistically favor cross-links. Apparently, ThT data conflict with $\beta$-structuration of $\mathrm{CK}_{4}$ detected in ATR-FITR; however, changes in the emission intensity of ThT fluorescence are not univocally attributed [48]. ThT increments were also detected as a consequence of the formation of highly fluorescent dimers [49], excimers [50], and even micelles of ThT itself [51]. Moreover, interactions limiting dye rotation and planarization may also lead to a remarkable increase in fluorescence intensity [52]. Lastly, other studies demonstrated the interference of solvent viscosity on ThT fluorescence behavior [53]. To this purpose, our data suggest that other mechanisms responsible for ThT absorption and fluorescence increments may take place in $\mathrm{CK}_{4}$ in addition to standard cross- $\beta$-sheet binding, like the probable influence of the long peptidic chain, causing highly-viscous solutions (see rheology section), responsible for unusually high ThT fluorescence.

\subsection{Morphology}

Nanostructural topography was characterized in both $\mathrm{CK}_{n}$ and crossCK $\mathrm{K}_{\mathrm{n}}$. AFM results confirmed that $\mathrm{CK}_{1}, \mathrm{CK}_{2}, \mathrm{CK}_{3}$ and $\mathrm{CK}_{4}$ self-assemble into nanofibers with an average nanofiber width of $15 \pm 1.5 \mathrm{~nm}$. On the other hand, $\operatorname{cross} \mathrm{CK}_{1}, \operatorname{cross}_{\mathrm{C}} \mathrm{K}_{2}, \operatorname{crossCK}_{3}$ and cross $\mathrm{CK}_{4}$ featured nanofibers with an average width of $30 \pm 1.2 \mathrm{~nm}$, significantly larger than their not cross-linked counterparts. (Figure 6).
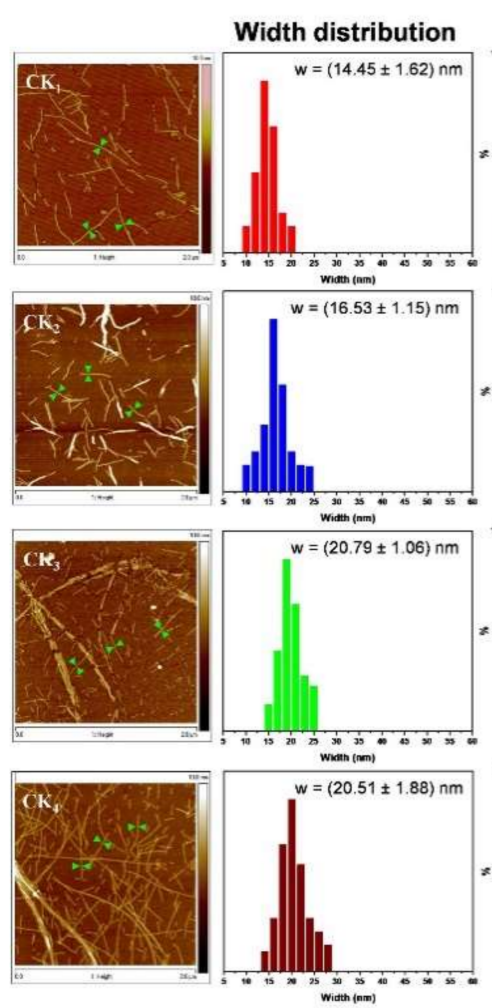
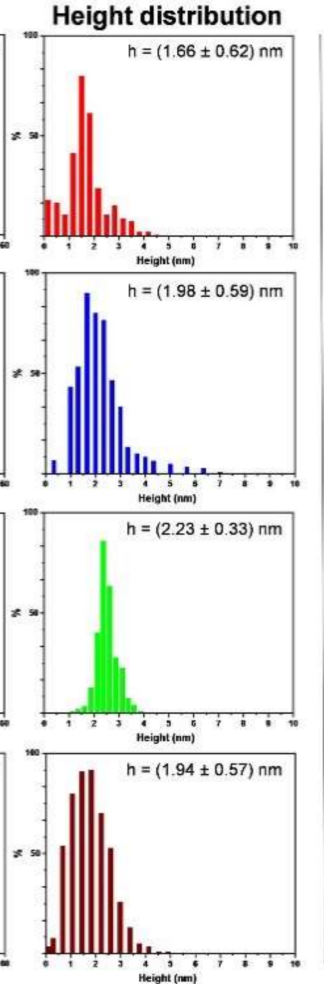
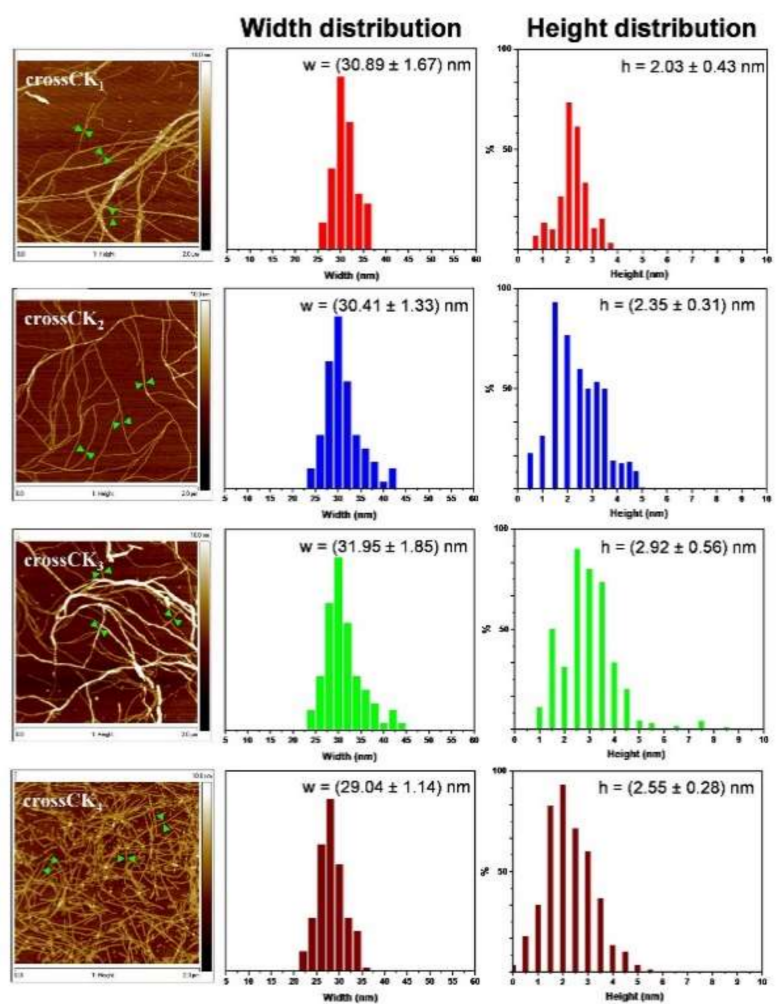

Figure 6. AFM images of $\mathrm{CK}_{n}$ peptides (left) and crossCK $\mathrm{K}_{\mathrm{n}}$ peptides (right) with corresponding height and width distributions. Overall, the cross-linking reaction increased the interactions among nanofibers, yielding to higher and larger bundles of fibers. Height and width profiles were measured using a population of $\sim 50$ fibers per each sample. As an example, green arrowheads point at where width profiles were measured. 
This increment is likely given by a higher level of bundling of multiple nanofibers favored by the cross-linking reaction. Interestingly, the gradual increase of fiber width detected from $\mathrm{CK}_{1}$ to $\mathrm{CK}_{3}$ is easily explained with their increased overall peptide chain length, crucial feature when molecular are perpendicular to the nanofiber axis as in cross- $\beta$ structures $[54,55]$.

We also characterized the nanofiber height distribution of $\mathrm{CK}_{n}$ and $\operatorname{crossCK}_{n}$ (Figure 6): AFM analysis revealed similar values among the four uncross-linked SAPs with a height distribution between $1.66 \mathrm{~nm}$ and $2.23 \mathrm{~nm}$, while the height distribution for crossCK $\mathrm{K}_{\mathrm{n}}$ laid between $2.03 \mathrm{~nm}$ and $2.92 \mathrm{~nm}$, revealing a 20\% height increment after Sulfo-SMCC crosslinking. Nevertheless, neither $\mathrm{CK}_{4}$ nor crossCK 4 exceeded height and width distribution values detected, respectively in $\mathrm{CK}_{3}$ and cross $\mathrm{CK}_{3}$, seemingly to point out a correlation with the lower mechanical performances of $\mathrm{CK}_{4}$ and crossCK$_{4}$. The persistence length $(\lambda)$ of the detected nanofibers (See Supplementary Methods and Figure S5 in Supplementary Materials) was calculated via the mean-squared midpoint displacement (MSMD) method (characterizing the straightness of nanofibers) and here used as a "geometric" evaluation of their mechanical stiffness [56]. High values of $\lambda$ suggest that $\mathrm{CK}_{n}$ and crossCK $\mathrm{K}_{n}$ nanofibers can be classified as very stiff fibrillar-like objects (see Supplementary Materials, Figure S5) [57].

\subsection{Orthogonal Double Cross-Linking}

Since crossCK $\mathrm{K}_{\mathrm{n}}$ still featured a residual percentage of free amine groups (TNBSA assay), we aimed at boosting SAP mechanical increments with an additional cross-linking reaction after the first one with Sulfo-SMCC. To this purpose, we chose GP, an aglycone extracted from the iridoid glycoside geniposide present in Gardenia Jasminoides, that can undergo a spontaneous reaction with primary amines present in amino acids [58]. In our previous works, we reported such a cross-linking strategy as being non-cytotoxic for human neural stem cells (hNSC) and of great potential for regenerative medicine applications [6,59].

ATR-FTIR data showed increments of $\beta$-sheets component in the Amide I region (peak $1695 \mathrm{~cm}^{-1}$ ) for crossCK $1-3$-GP, but similarly to Sulfo-SMCC cross-linking, not relevant for crossCK ${ }_{4}$ GP (Figure 7a and Figure S6). The absorption peaks of GP after $24 \mathrm{~h}$ are shown in Figure S7.

(a)

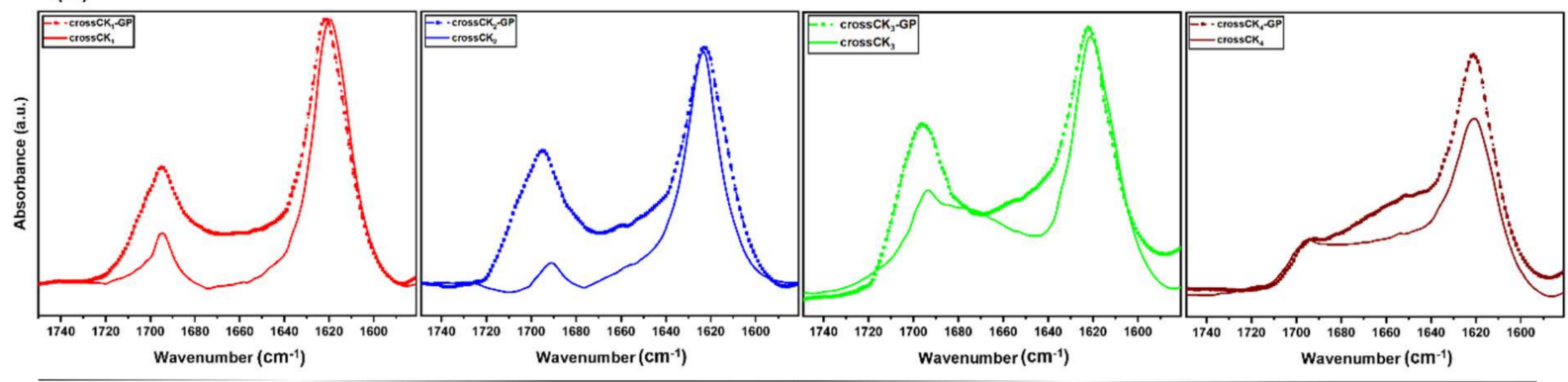

(b)

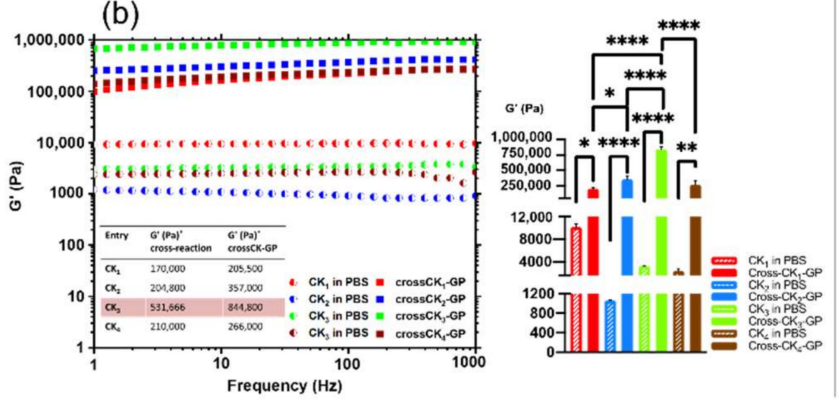

(c)

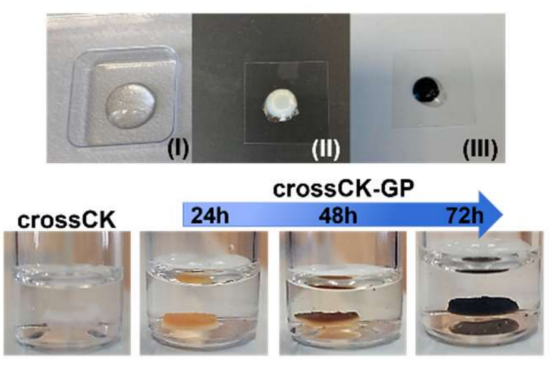

Figure 7. CrossCK $\mathrm{K}_{\mathrm{s}}$-GP experiments. (a) Experimental ATR-FTIR absorption spectra of crossCK and crossCKn-GP. (b) Rheological tests of crossCK $\mathrm{C}_{n}-\mathrm{GP}$ with respective average $\mathrm{G}^{\prime}$ values: crossCK$_{3}$ GP (highlighted in red) showed the highest value of $\mathrm{G}^{\prime}(844 \pm 41) \mathrm{kP} .{ }^{*} p<0.05,{ }^{* *} p>0.01$ and ***** $p<0.0001$. (c) Orthogonal double cross-linking reaction at the macroscale: (I) $C_{n}$ in water solution, (II) after self-assembling and Sulfo-SMCC reaction, (III) after additional GP cross-linking. Below, imaging of the typical change of color of cross $\mathrm{CK}_{\mathrm{n}}$-GP over time as a consequence of GP cross-linking. 
Accordingly, GP cross-linking bestowed crossCK $\mathrm{K}_{1-3}$ with significantly increased values of $\mathrm{G}^{\prime}$ reaching $(205 \pm 20) \mathrm{kPa}\left(\operatorname{crossCK}_{1}-\mathrm{GP}\right),(357 \pm 55) \mathrm{kPa}\left(\operatorname{crossCK}_{2}-\mathrm{GP}\right),(844 \pm 41) \mathrm{kPa}$ (crossCK $\left.\mathrm{K}_{3}-\mathrm{GP}\right)$, but with a limited increment for (crossCK $\left.\mathrm{CK}_{4}-\mathrm{GP}\right)$, where it jumped from $(208 \pm 64) \mathrm{kPa}$ to $(266 \pm 70) \mathrm{kPa}$ (Figure 7b). Even after GP cross-linking, where all scaffolds turned into a blueish color testifying GP cross-linking (Figure 7c), G" values were well below the corresponding $\mathrm{G}^{\prime}$ ones (Figure S6c), testifying the solid behavior of all crossCK $\mathrm{n}^{-}$ GP scaffolds. Table S3 (Supplementary Materials) compares current results with other cross-linking strategies adopted with SAPs: to the best of our knowledge, cross-CKs and cross-CKs-GP show the highest $\mathrm{G}^{\prime}$ values obtained with pure SAPs so far.

\section{Conclusions}

Despite the promising potential of SAPs for tissue engineering applications, the usage of such biomimetic versatile scaffolds has been hampered by their poor mechanical properties limiting their applications to fillers or soft tissue replacements [43]. In this work, we designed new SAPs specifically to exploit the Sulfo-SMCC cross-liking approach in terms of stiffer SAP-based nanomaterials. We also demonstrated the feasibility of the orthogonal double cross-linking strategy aimed at bringing $\mathrm{G}^{\prime}$ values as high as $844 \mathrm{kPa}$, thus bringing SAP constructs closer to stiffnesses of cardiac tissue, osteoids and skin. Such enhancements came at no cost of the self-assembling propensity of the tested $\mathrm{CK}_{\mathrm{n}}$ : as such they could be applied to a good number of already existing SAPs comprising Lys and Cys in their sequences. Our work demonstrates that multiple selective cross-linking strategies can be taken into account for SAP design, but it also shows some technical limits arising from the unbalanced chain of $\mathrm{CK}_{4}$, where long functional motifs hamper appropriate self-assembling and active sites availability for cross-linking. In summary, we laid new theory for the design of cross-linked SAPs, ready to be applied, together with their tuned functionalizations, for the development of stiffer biomimetic scaffolds for the regeneration of different tissues with stiffnesses between $105 \mathrm{~Pa}$ and $106 \mathrm{~Pa}$, like, for example, including bone tissue, articular cartilage, and tendon connective tissue.

Supplementary Materials: The following supporting information can be downloaded at: https:/ / www.mdpi.com/article/10.3390/nano12030320/s1, Figure S1: G" (loss moduli) values; Figure S2: Cross-linking reaction of $\mathrm{CK}_{3}$ and $\mathrm{CK}_{4}$ at different concentrations and incubation times; Figure S3: Figure S3. G" (loss moduli) values of $\mathrm{CK}_{3}$ and $\mathrm{CK}_{4}$ at different concentrations and incubation times; Figure S4. Deconvolution of ATR-FTIR absorption spectra of $\mathrm{CK}_{1-4}$ in the Amide I band; Figure S5: Persistence length; Figure S6: CrossCK $\mathrm{K}_{\mathrm{n}}$ GP experiments; Figure S7: ATR-FTIR absorption spectra of Genipin; Table S1: G' values of cross-linking reaction of $\mathrm{CK}_{3}$ and $\mathrm{CK}_{4}$ at different concentrations and incubation times. Table S2: $\mathrm{G}^{\prime \prime}$ values of cross-linking reaction of $\mathrm{CK}_{3}$ and $\mathrm{CK}_{4}$ at different concentrations and incubation times. Table S3. Comparison table of different $\mathrm{G}^{\prime}$ (storage modulus) obtained in other similar works.

Author Contributions: Conceptualization, M.G.C., R.P. and F.G.; methodology, M.G.C. and R.P.; validation, M.G.C.; formal analysis, M.G.C. and R.P.; investigation, M.G.C., R.P. and F.G.; data curation, M.G.C.; writing — original draft preparation, M.G.C.; supervision, F.G.; funding acquisition, F.G. All authors have read and agreed to the published version of the manuscript.

Funding: Author's funding was granted by INAIL (BRIC2019-ID25) and by the Italian Ministry of Health (Ricerca Corrente 2018-2021) and by the " $5 \times 1000$ " voluntary contributions. Financial support also came from Revert Onlus.

Data Availability Statement: No public archived data were generated during this study. Data are made available by the authors upon request.

Acknowledgments: The authors would like to thank Luca Campone from University of MilanBicocca, for his helpful advice with QTof measurements, and Mattia Usuelli from ETH Zürich, for his valuable advice on FiberApp routines and persistence length measurements.

Conflicts of Interest: The authors declare no conflict of interest. 


\section{References}

1. Zhang, S.G. Fabrication of novel biomaterials through molecular self-assembly. Nat. Biotechnol. 2003, 21, 1171-1178. [CrossRef]

2. Rest, C.; Kandanelli, R.; Fernández, G. Strategies to create hierarchical self-assembled structures via cooperative non-covalent interactions. Chem. Soc. Rev. 2015, 44, 2543-2572. [CrossRef] [PubMed]

3. Lehn, J.M. Supramolecular Chemistry: Concepts and Perspectives; VCH: Weinheim, Germany, 1995.

4. $\quad$ Rad-Malekshahi, M.; Visscher, K.M.; Rodrigues, J.P.G.L.M.; De Vries, R.; Hennink, W.E.; Baldus, M.; Bonvin, A.M.J.J.; Mastrobattista, E.; Weingarth, M. The Supramolecular Organization of a Peptide-Based Nanocarrier at High Molecular Detail. J. Am. Chem. Soc. 2015, 137, 7775-7784. [CrossRef] [PubMed]

5. Matson, J.B.; Stupp, S.I. Self-assembling peptide scaffolds for regenerative medicine. Chem. Commun. 2012, 48, 26-33. [CrossRef]

6. Saracino, G.A.A.; Cigognini, D.; Silva, D.; Caprini, A.; Gelain, F. Nanomaterials design and tests for neural tissue engineering. Chem. Soc. Rev. 2013, 42, 225-262. [CrossRef]

7. Yang, H.N.; Yang, H.L.; Xie, Z.H.; Wang, P.; Bi, J.Z. Self-assembling nanofibers alter the processing of amyloid precursor protein in a transgenic mouse model of Alzheimer's disease. Neurol. Res. 2015, 37, 84-91. [CrossRef] [PubMed]

8. Gelain, F.; Panseri, S.; Antonini, S.; Cunha, C.; Donega, M.; Lowery, J.; Taraballi, F.; Cerri, G.; Montagna, M.; Baldissera, F.; et al. Transplantation of nanostructured composite scaffolds results in the regeneration of chronically injured spinal cords. ACS Nano 2011, 5, 227-236. [CrossRef]

9. Guo, J.S.; Leung, K.K.; Su, H.X.; Yuan, Q.J.; Wang, L.; Chu, T.H.; Zhang, W.M.; Pu, J.K.S.; Ng, G.K.P.; Wong, W.M.; et al. Self-assembling peptide nanofiber scaffold promotes the reconstruction of acutely injured brain. Nanomed. Nanotechnol. Biol. Med. 2009, 5, 345-351. [CrossRef]

10. Liu, J.; Song, H.; Zhang, L.; Xu, H.; Zhao, X. Self-assembly-peptide hydrogels as tissue-engineering scaffolds for three-dimensional culture of chondrocytes in vitro. Macromol. Biosci. 2010, 10, 1164-1170.

11. Tsuda, Y.; Morimoto, Y.; Takeuchi, S. Monodisperse cell-encapsulating peptide microgel beads for 3D cell culture. Langmuir 2010, 26, 2645-2649. [CrossRef] [PubMed]

12. Henninot, A.; Collins, J.C.; Nuss, J.M. The Current State of Peptide Drug Discovery: Back to the Future? J. Med. Chem. 2018, 61, 1382-1414. [CrossRef] [PubMed]

13. Yang, J.; An, H.W.; Wang, H. Self-Assembled Peptide Drug Delivery Systems. ACS Appl. Bio Mater. 2020, 4, 24-46. [CrossRef] [PubMed]

14. Peressotti, S.; Koehl, G.E.; Goding, J.A.; Green, R.A. Self-Assembling Hydrogel Structures for Neural Tissue Repair. ACS Biomater. Sci. Eng. 2021, 7, 4136-4163. [CrossRef] [PubMed]

15. Demichelis, A.; Pavarelli, S.; Mortati, L.; Sassi, G.; Sassi, M. Study on the AFM Force Spectroscopy method for elastic modulus measurement of living cells. J. Phys. Conf. Ser. 2013, 459, 012050. [CrossRef]

16. Sasaki, N.; Odajima, S. Stress-strain curve and young's modulus of a collagen molecule as determined by the X-ray diffraction technique. J. Biomech. 1996, 29, 655-658. [CrossRef]

17. Kolahi, K.S.; Donjacour, A.; Liu, X.; Lin, W.; Simbulan, R.K. Effect of Substrate Stiffness on Early Mouse Embryo Development. PLoS ONE 2012, 7, e41717. [CrossRef] [PubMed]

18. Autumn, K.; Gravish, N. Gecko adhesion: Evolutionary nanotechnology. Philos. Trans. R. Soc. A 2008, 366, 1575-1590. [CrossRef] [PubMed]

19. Majidi, C. Soft Robotics: A Perspective-Current Trends and Prospects for the Future. Soft Robot. 2014, 1, 5-11. [CrossRef]

20. Autumn, K.; Majidi, C.; Groff, R.E.; Dittmore, A.; Fearing, R. Effective elastic modulus of isolated gecko setal arrays. J. Exp. Biol. 2006, 209, 3558-3568. [CrossRef] [PubMed]

21. Marchini, A.; Raspa, A.; Pugliese, R.; El Malek, M.A.; Pastori, V.; Lecchi, M.; Vescovi, A.L.; Gelain, F. Multifunctionalized hydrogels foster hNSC maturation in 3D cultures and neural regeneration in spinal cord injuries. Proc. Natl. Acad. Sci. USA 2019, 116, 7483-7492. [CrossRef] [PubMed]

22. Mattson, G.; Conklin, E.; Desai, S.; Nielander, G.; Savage, M.D.; Morgensen, S. A practical approach to crosslinking. Mol. Biol. Rep. 1993, 17, 167-183. [CrossRef]

23. Li, Y.; He, Q.; Hu, X.; Liu, Y.; Cheng, X.; Li, X.; Deng, F. Improved performance of collagen scaffolds crosslinked by Traut's reagent and Sulfo-SMCC. J. Biomater. Sci. Polym. Ed. 2017, 28, 629-647. [CrossRef]

24. Brinkley, M. A brief survey of methods for preparing protein conjugates with dyes, haptens and crosslinking reagents. Bioconjug. Chem. 1992, 3, 2-13. [CrossRef]

25. Partis, M.D.; Griffiths, D.G.; Roberts, G.C.; Beechey, R.B. Cross-linking of protein by $\omega$-maleimido alkanoylN-hydroxysuccinimido esters. J. Protein Chem. 1983, 2, 263-277. [CrossRef]

26. Hnasko, R. Bioconjugation of Antibodies to Horseradish Peroxidase (HRP). In ELISA; Methods in Molecular Biology; Humana Press: New York, NY, USA, 2015; Volume 1318, pp. 43-50.

27. Pugliese, R.; Marchini, A.; Saracino, G.A.A.; Zuckermann, R.N.; Gelain, F. Cross-linked self-assembling peptide scaffolds. Nano Res. 2018, 11, 586-602. [CrossRef]

28. Pugliese, R.; Maleki, M.; Zuckermann, R.N.; Gelain, F. Self-assembling peptides cross-linked with Genipin: Resilient hydrogels and self-standing electrospun scaffolds for tissue engineering applications. Biomater. Sci. 2019, 7, 76-91. [CrossRef]

29. Ji, Y.; Yang, X.; Ji, Z.; Zhu, L.; Ma, N.; Chen, D.; Jia, X.; JunTang, J.; Yilin, C. DFT-Calculated IR Spectrum Amide I, II, and III Band Contributions of N-Methylacetamide Fine Components. ACS Omega 2020, 5, 8572-8578. [CrossRef] [PubMed]

30. Xue, C.; Lin, T.Y.; Chang, D.; Guo, Z. Thioflavin T as an amyloid dye: Fibril quantification, optimal concentration and effect on aggregation. R. Soc. Open Sci. 2017, 4, 160696. [CrossRef] 
31. Pugliese, R.; Fontana, F.; Marchini, A.; Gelain, F. Branched peptides integrate into self-assembled nanostructures and enhance biomechanics of peptidic hydrogels. Acta Biomater. 2018, 66, 258-271. [CrossRef] [PubMed]

32. Carpenter, K.J. The estimation of the available lysine in animal-protein foods. Biochem. J. 1960, 77, 604-610. [CrossRef] [PubMed]

33. Ellman, G.L. Tissue sulfhydryl groups. Arch. Biochem. Biophys. 1959, 82, 70-77. [CrossRef]

34. Di Rocco, H.O.; Iriarte, D.I.; Pomarico, J. General Expression for the Voigt Function That is of Special Interest for Applied Spectroscopy. Appl. Spectrosc. 2001, 55, 822-826. [CrossRef]

35. Usov, I.; Mezzenga, R. FiberApp: An Open-Source Software for Tracking and Analyzing Polymers, Filaments, Biomacromolecules, and Fibrous Objects. Macromolecules 2015, 48, 1269-1280. [CrossRef]

36. Raspa, A.; Saracino, G.A.A.; Pugliese, R.; Silva, D.; Cigognini, D.; Vescovi, A.; Gelain, F. Complementary co-assembling peptides: From in silico studies to in vivo application. Adv. Funct. Mater. 2014, 24, 6317-6328. [CrossRef]

37. Taraballi, F.; Natalello, A.; Campione, M.; Villa, O.; Doglia, S.M.; Paleari, A.; Gelain, F. Glycine-spacers influence functional motifs exposure and self-assembling propensity of functionalized substrates tailored for neural stem cell cultures. Front. Neuroeng. 2010, 3, 1. [CrossRef]

38. Pugliese, R.; Gelain, F. Peptidic biomaterials: From self-assembling to regenerative medicine. Trends Biotechnol. 2016, 35, 145-158. [CrossRef]

39. Haines-Butterick, L.; Rajagopal, K.; Branco, M.; Salick, D.; Rughani, R.; Pilarz, M.; Lamm, M.S.; Pochan, D.J.; Schneider, J.P. Controlling hydrogelation kinetics by peptide design for three-dimensional encapsulation and injectable delivery of cells. Proc. Natl. Acad. Sci. USA 2007, 104, 7791-7796. [CrossRef]

40. Zhang, S.; Holmes, T.C.; Di Persio, C.M.; Hynes, R.O.; Su, X.; Rich, A. Self-complementary oligopeptide matrices support mammalian cell attachment. Biomaterials 1995, 16, 1385-1393. [CrossRef]

41. Zhang, W.; Zhang, Y.; Su, Z.; Wei, G. Green synthesis and fabrication of an electrochemical and colorimetric sensor based on self-assembled peptide-Au nanofibril architecture. Arab. J. Chem. 2020, 13, 1406-1414. [CrossRef]

42. Taraballi, F.; Campione, M.; Sassella, A.; Vescovi, A.; Paleari, A.; Hwang, W.; Gelain, F. Effect of functionalization on the self-assembling propensity of $\beta$-sheet forming peptides. Soft Matter 2009, 5, 660-668. [CrossRef]

43. Gelain, F.; Luo, Z.; Zhang, S. Self-Assembling Peptide EAK16 and RADA16 Nanofiber Scaffold Hydrogel. Chem. Rev. 2020, 120, 13434-13460. [CrossRef] [PubMed]

44. Chen, P. Self-assembly of ionic-complementary peptides: A physicochemical viewpoint. Colloids Surf. A Physicochem. Eng. Aspect. 2005, 261, 3-24. [CrossRef]

45. Seshadri, S.; Khurana, R.; Fink, A.L. Fourier transform infrared spectroscopy in analysis of protein deposits. Methods Enzymol. 1999, 309, 559-576. [PubMed]

46. Parker, F.S. Amides and Amines. Applications of Infrared Spectroscopy in Biochemistry, Biology, and Medicine; Plenum Press: New York, NY, USA, 1971; pp. 165-172.

47. Iqbal, J.; Shahnaz, G.; Dünnhaupt, S.; Müller, C.; Hintzen, F.; Bernkop-Schnürch, A. Preactivated thiomers as mucoadhesive polymers for drug delivery. Biomaterials 2012, 33, 1528-1535. [CrossRef] [PubMed]

48. Lindberg, D.J.; Wranne, M.S.; Gatty, M.G.; Westerlund, F.; Esbjörner, E.K. Steady-state and time-resolved Thioflavin-T fluorescence can report on morphological differences in amyloid fibrils formed by $\mathrm{A} \beta(1-40)$ and $\mathrm{A} \beta(1-42)$. Biochem. Biophys. Res. Commun. 2015, 458, 418-423. [CrossRef]

49. Ramamurthy, V.; Sanderson, D.R.; Eaton, D.F. Control of dye assembly within zeolites: Role of water. J. Am. Chem. Soc. 1993, 115, 10438-10439. [CrossRef]

50. Lingling, L.; Yong, S.; Jian, P.; Hua, L.; Lihua, Z. Selective recognition of ds-DNA cavities by a molecular rotor: Switched fluorescence of thioflavin T. Mol. BioSyst. 2013, 9, 2512-2519.

51. Groenning, M.; Olsen, L.; Van De Weert, M.; Flink, J.M.; Frokjaer, S.; Jørgensen, F. Study on the binding of Thioflavin T to $\beta$-sheet-rich and non- $\beta$-sheet cavities. J. Struct. Biol. 2007, 158, 358-369. [CrossRef]

52. Babenko, V.; Dzwolak, W. Thioflavin T forms a non-fluorescent complex with alpha-helical poly-L-glutamic acid. Chem. Commun. 2011, 47, 10686-10688. [CrossRef] [PubMed]

53. Friedho, V.P.; Schneider, A.; Mandelkow, E.M.; Mandelkow, E. Rapid assembly of Alzheimer-like paired helical filaments from micro-tubule-associated protein tau monitored by fluorescence in solution. Biochemistry 1998, 37, 10223-10230. [CrossRef] [PubMed]

54. Gelain, F.; Bottai, D.; Vescovi, A.L.; Zhang, S. Designer Self-Assembling Peptide Nanofiber Scaffolds for Adult Mouse Neural Stem Cell 3-Dimensional Cultures. PLoS ONE 2006, 1, e119. [CrossRef]

55. Horii, A.; Wang, X.; Gelain, F.; Zhang, S. Biological Designer Self-Assembling Peptide Nanofiber Scaffolds Significantly Enhance Osteoblast Proliferation, Differentiation and 3-D Migration. PLoS ONE 2007, 2, e190. [CrossRef] [PubMed]

56. Broedersz, C.P. Modeling semiflexible polymer networks. Rev. Mod. Phys. 2014, 86, 995. [CrossRef]

57. Cao, Y.; Bolisetty, S.; Adamcik, J.; Mezzenga, R. Elasticity in Physically Cross-Linked Amyloid Fibril Networks. Phys. Rev. Lett. 2018, 120, 158103. [CrossRef]

58. Fujikawa, S.; Fukui, Y.; Koga, K.; Iwashita, T.; Komura, H.; Nomoto, K. Structure of genipocyanin G1, a spontaneous reaction product between genipin and glycine. Tetrahedron Lett. 1987, 28, 4699-4700. [CrossRef]

59. Pugliese, R.; Moretti, L.; Maiuri, M.; Romanazzi, T.; Cerullo, G.; Gelain, F. Superior mechanical and optical properties of a heterogeneous library of cross-linked biomimetic self-assembling peptides. Mater. Des. 2020, 194, 108901. [CrossRef] 